\title{
Prospective Application of Two New Pyridine-Based Zinc (II) Amide Carboxylate in Management of Alzheimer's Disease: Synthesis, Characterization, Computational and in vitro Approaches
}

\author{
Rehman Zafar ${ }^{1,2}$ \\ Humaira Naureen (iD) ${ }^{3}$ \\ Muhammad Zubair ${ }^{4}$ \\ Khadija Shahid' \\ Muhammad Saeed Jan (iD ${ }^{5}$ \\ Samar Akhtar ${ }^{2}$ \\ Hammad Ahmad ${ }^{2}$ \\ Wajeeha Waseem ${ }^{6}$ \\ Ali Haider ${ }^{4}$ \\ Saqib $\mathrm{Ali}^{4}$ \\ Muhammad Tariq (D) ${ }^{7}$ \\ Abdul Sadiq ${ }^{8}$
}

'Department of Pharmaceutical Chemistry, Faculty of Pharmaceutical Sciences, Riphah International University, Islamabad, 44000. Pakistan; ${ }^{2}$ Yusra Institute of Pharmaceutical Sciences, Islamabad, 44000, Pakistan;

${ }^{3}$ Department of Pharmacognosy, Faculty of

Pharmaceutical Sciences, Riphah Internationa University, Islamabad, 44000, Pakistan;

${ }^{4}$ Department of Chemistry, Quaid-i-Azam

University, Islamabad, 45320, Pakistan;

${ }^{5}$ Department of Pharmacy, University of Swabi,

Swabi, KP, Pakistan; ${ }^{6}$ Department of Basic

Medical Sciences, Faculty of Pharmaceutical

Sciences, Riphah International University,

Islamabad, 44000, Pakistan; ${ }^{7}$ Department of

PCB, Rokhan University, Jalalabad, Nangrahar,

Afghanistan; ${ }^{8}$ Department of Pharmacy,

University of Malakand, Chakdara, KP, Pakistan

Correspondence: Abdul Sadiq

Department of Pharmacy, University of

Malakand, Chakdara, 18000 Dir (L), KP,

Pakistan

Tel +92-332-5046485

Email sadiquom@yahoo.com

Saqib Ali

Department of Chemistry, Quaid-i-Azam

University, Islamabad, 45320, Pakistan

Email drsa54@hotmail.com
Background: Alzheimer's disease (AD) is a neurodegenerative illness described predominantly by dementia. Even though Alzheimer's disease has been known for over a century, its origin remains a mystery, and researchers are exploring many therapy options, including the cholinesterase technique. A decreased acetylcholine ACh neurotransmitter level is believed to be among the important factors in the progression of Alzheimer's disease.

Methods: In continuation of synthesizing potential anti-Alzheimer agents and known appreciative pharmacological potential of amide-containing compounds, this study presents the synthesis of two novel amide-based transition metal zinc (II) complexes, AAZ7 and AAZ8, attached with a heterocyclic pyridine ring, which was synthesized and characterized by Fourier transform infrared spectroscopy (FT-IR), elemental analysis, ${ }^{1} \mathrm{H}_{-}$NMR, and ${ }^{13} \mathrm{C}_{-}$NMR. FT-IR spectroscopic records showed the development of bidentate ligand as $\Delta v$ value was decreased in both complexes when compared with the free ligand. Both of the synthesized complexes were analyzed for acetylcholinesterase and butyrylcholinesterase inhibitory potential along with the antioxidizing activity.

Results: Importantly, the complex of AAZ8 exhibited more potent activity giving $\mathrm{IC}_{50}$ values of $14 \mu \mathrm{g} / \mathrm{mL}$ and $18 \mu \mathrm{g} / \mathrm{mL}$ as $\mathrm{AChE}$ and $\mathrm{BChE}$ cholinesterase inhibitors, respectively, when compared with standard positive control galantamine. Interestingly, AAZ8 also displayed promising antioxidant potential by showing $\mathrm{IC}_{50}$ values of $35 \mu \mathrm{g} /$ $\mathrm{mL}$ for DPPH and $29 \mu \mathrm{g} / \mathrm{mL}$ for ABTS in comparison with positive control ascorbic acid.

Conclusion: Herein, we report two new amide carboxylate zinc (II) complexes which were potentially analyzed for various biological applications like acetylcholinesterase (AChE), butyrylcholinesterase (BChE) inhibitory potentials, and antioxidant assays. Computational docking studies also simulated results to understand the interactions. Additionally, thermodynamic parameters utilizing molecular dynamic simulation were performed to determine the ligand protein stability and flexibility that supported the results. Studies have shown that these compounds have the potential to be good anti-Alzheimer candidates for future studies due to inhibition of cholinesterase enzymes and display of free radical scavenging potential against DPPH as well as ABTS free radicals.

Keywords: $\mathrm{Zn}(\mathrm{II})$ carboxylate, acetylcholinesterase, butyrylcholinesterase, elemental analysis, docking studies 


\section{Introduction}

Alzheimer's disease (AD) is a severe brain abnormality that slowly destroys a person's thinking ability, and memory loss occurs. ${ }^{1}$ The person is unable to perform their everyday tasks, and physiological changes take place. ${ }^{2}$ It results in paranoia, dementia, restlessness, anxiety, and aggression. $^{3}$ Symptoms of Alzheimer's disease first appeared in the mid-60s. It is ranked as the sixth leading cause of death in the US. ${ }^{4}$ Over 50 million individuals globally are thought to have dementia, with around 10 million instances identified every day. ${ }^{5}$

Several hypotheses are proposed regarding Alzheimer's disease, including the $A \beta$ amyloid hypothesis, A $\beta$ amyloid oligomer hypothesis, Presenilin hypothesis, Calcium dysfunction hypothesis, lysosome hypothesis, and the Tau hypothesis. ${ }^{6}$ The A $\beta$ Amyloid hypothesis is believed to be among the renowned hypotheses. ${ }^{7}$ Researchers also reveal that Alzheimer's disease might result from an infection by oral bacteria Plasmodium gingivalis. ${ }^{8}$ Toxins produced by these bacteria are called gingipains that accumulate in the brain. The effects of Alzheimer's disease vary from person to person and can be understood in three stages. ${ }^{9,10}$ In the first stage, a patient undergoes forgetfulness, loses track of time, and becomes lost in familiar places. In the second stage, behavioral changes, feelings of loss at home, needing help for personal care, and difficult communication occur. ${ }^{11}$ In the third stage of disease, a patient undergoes difficulty recognizing relatives and friends, an increased need for selfcare, difficulty walking, unaware of time and place, and behavioral changes like aggression occur. ${ }^{12}$ Several tests and investigative procedures are performed for the diagnosis of Alzheimer's disease. ${ }^{13,14}$ The peanut Butter test involves measuring the ability of people to smell peanut butter through each nostril. ${ }^{15}$ Research proved that people with $\mathrm{AD}$ were not able to smell peanut butter. ${ }^{16} \mathrm{~A}$ latest blood test that predicts Alzheimer's disease 10 years before the disease occurs. ${ }^{17,18}$ Researchers from NIOA focus on a protein in the brain, ie, IRS-I, that may signal the earliest stages of $\mathrm{AD} .{ }^{19,20} \mathrm{~A}$ decrease in the neurotransmitter acetylcholine ACh has been closely related to the prognosis of Alzheimer's disease. ${ }^{21}$ The pathogenesis of Alzheimer's disease has been strongly linked to a deficiency in brain neurotransmitter Acetylcholine. ${ }^{22,23}$ Scientists and physicians need to learn more and more about Alzheimer's disease and dementia, but in general still, no cure has been found. ${ }^{24}$ Some medications lead to the symptomatic cure of disease like treating memory loss and confusion, including acetylcholinesterase enzyme inhibitors. ${ }^{25}$ They protect from free radical poisonousness and injury generated by $\beta$ amyloid and temper cytokine discharge through microglia. ${ }^{26,27}$

Amide-based carboxylate derivatives play a significant part in the cure of this pathogenic illness. ${ }^{28}$ They make strong interactions with biological receptors and undergo dual strategies by inhibiting the acetylcholinesterase to increase the quantity of acetylcholine and by performing as antioxidants. ${ }^{18,29}$ Many drugs, including Tacrine, Donepezil, Rivastigmine, and Galantamine, are available. ${ }^{30,31}$ Rivastigmine is a FDA-approved carbamate ester having amide linkage and a reversible cholinesterase inhibitor. ${ }^{32}$ One emerging intervention is metal carboxylates that have gained massive attention in past decades due to their fascinating structural design and their application in pharmaceuticals as drugs. ${ }^{33}$ Complexes of metals like magnesium, copper, iron, bismuth, and zinc have been a target of research for the last two decades. ${ }^{34}$ Many new moieties have been synthesized and tested for anti-microbial, anti-fungal, anti-cancerous, anti-leishmanial, antiinflammatory, anti-bacterial, and other biological activities. It is proved to be having several effects. ${ }^{35}$ For all of the above, the catalytic research result could be altered by altering the structure of synthesized compound electronic configuration and their target receptors.

Zinc predominates over other metals like copper and iron due to the $80-90 \%$ highly bound appearance of zinc with protein pools chelatables that could be visualized through chemical probes and histochemical analysis. ${ }^{36}$ A specific concentration of zinc appeared as vesicles have predominant effects upon dopamine receptors, acetylcholine receptors, and sodium potassium voltage gated ion channels. ZnT-1 and ZnT-3 are responsible for the reuptake of zinc in vesicles, thus decreasing the chances of toxicity. ${ }^{37} \mathrm{Zn}$ (II) carboxylates are extraordinary in multiple ways as they form different mono or bidentate modes of interactions. These types of zinc complexes have made a huge number of coordination compounds that can be identified for biochemical purposes. The intercalation of pyridyl, pyrimidyl, pyrazoles, N-N bipyridines, piperidine, anthracillins, and substituted guanidine keep excellent potential to coordinate and their addition to the zinc complexes provide flexible physical and biochemical properties that cover a wide range of stability and activity. 
Many pyridyls, pyrimidyl, pyrazoles, N-N bipyridines, piperidine, anthracillins, and substituted guanidine have been intercalated with metals like zinc to enhance their metabolic functions and characteristics. ${ }^{38,39}$ In this research, pyridine was attached. It has been observed that this pyridine attached as a heterocyclic compound gave the predominant effect ${ }^{40}$ upon the catalytic properties and affinities to the binding site of receptors. Herein, the synthesis and characterization of two new compounds were carried out to recognize potential towards biological moieties, especially acetylcholinesterase, butyrylcholinesterase, and antioxidant activities.

\section{Materials and Methods Chemistry}

Two carboxylic acid derivatives, namely Ligand $7\left(\mathrm{HL}^{7}\right)$ and Ligand $8\left(\mathrm{HL}^{8}\right)$, were synthesized in the laboratory by our following reported method. ${ }^{41} \mathrm{Zn}\left(\mathrm{NO}_{3}\right)_{2} \cdot 6 \mathrm{H}_{2} \mathrm{O}$, $\mathrm{NaHCO}_{3}$, and pyridine were acquired from SigmaAldrich corporation (St Louis, MO; Analytical Grade) and used as such without further purification. Analytical grade solvents like dimethyl sulfoxide, ethanol, hydrochloric acid, methanol, glacial acetic acid, chloroform, and acetone were acquired from Merck (Germany) Ltd (Serono, Darmstadt). They were dried before use by the literature-reported method. ${ }^{41}$ Gallenkamp (UK) electrothermal apparatus was utilized to identify the melting points of the synthesized compounds. A Bruker Corporation USA (Billerica, MA) manufactured FT-IR Spectrophotometer in the range of 4,000 to $400 \mathrm{~cm}^{-1}$ was used to record the IR spectra. ${ }^{1} \mathrm{H}$ and ${ }^{13} \mathrm{CNMR}$ spectra were documented at room temperature using deuterated dimethyl sulfoxide (DMSO- $\mathrm{d}_{6}$ ) as an internal reference on a Bruker Advanced Digital (Switzerland) $300 \mathrm{MHz}$ NMR spectrometer $[\delta 1 \mathrm{H}(\mathrm{DMSO})=2.5 \mathrm{ppm}$ and $\delta 13 \mathrm{C}$ $(\mathrm{DMSO})=40 \mathrm{ppm}]$.

\section{General Procedure for the Synthesis of the Sodium Salt of Ligand 7 and Ligand 8 $\left(\mathrm{NaL}^{7}\right.$ and $\mathrm{NaL}^{8}$ )}

These two starting compounds were synthesized and acquired by protocols as published in our previous research work (AAZ1-AAZ6). ${ }^{42}$ The sodium salts of $\mathrm{HL}^{7}$ and $\mathrm{HL}^{8}$ were prepared by drop-wise addition of sodium bicarbonate aqueous solution $(2.5 \mathrm{mmol})$ into the ligands suspended solutions $(2.5 \mathrm{mmol})$, as demonstrated in Scheme 1. Continuous stirring was carried out for 4-5 hours until the clear solution appeared. Completion of the reaction was confirmed by thinlayer chromatography. The resulting mixture was allowed to run on a high vacuum rotary evaporator to evaporate distilled water and left with $\mathrm{NaL}^{7}$ and $\mathrm{NaL}^{8}$. Then this sodium salt of the ligands was further used for complex formation.

\section{(\{3-[(2-Methoxy-5-Nitrophenyl) Carbamoyl] Propanoyl\} Zincio 3-[(2-Methoxy-5-Nitrophenyl) Carbamoyl] Propanoate) Pyridine [ $\mathrm{Zn}$ $\left(\mathrm{L}^{7}\right)_{2}$ (Pyridine)] (AAZ 7)}

To $7 \mathrm{mmol}$ of an aqueous solution of $\mathrm{NaL}^{7}$, an immediate aqueous solution $(3.5 \mathrm{mmol})$ of $\mathrm{Zn}$ $\left(\mathrm{NO}_{3}\right)_{2} \cdot 6 \mathrm{H}_{2} \mathrm{O}$ was poured in a drop-wise manner with electric stirring followed by $(3.5 \mathrm{mmol})$ pyridine methanolic solution, as shown in Scheme 1. The resulting mixture was allowed to run with stirring till precipitates appeared. The precipitate formed was filtered, thoroughly washed with distilled water to remove any unreacted starting material, and dried in a vacuum oven overnight. The final product was recrystallized from the mixture of chloroform and n-hexane (4:1) at ambient temperature.

Yield: 87\%: M.P. $201-203^{\circ} \mathrm{C}$ : Mol. Wt.: $678.9 \mathrm{~g} / \mathrm{mol}$ : Anal. Calc. (\%) of $\mathrm{C}_{27} \mathrm{H}_{27} \mathrm{~N}_{5} \mathrm{O}_{12} \mathrm{Zn}$ : Calculated (Obtained): C, 47.77 (47.36); H, 4.01 (3.98); N, 10.32 (10.42); O, 28.35 (28.28); Zn, 9.32 (9.638): FT-IR KBr $(4,000-400) v / \mathrm{cm}^{-1}, 3,326 \vee(\mathrm{NH}) ; 1,641 \vee\left(\mathrm{CO}_{\text {amide }}\right)$; $1,519 v\left(\mathrm{OCO}_{\text {asym }}\right) ; 1330 v(\mathrm{OCO})_{\text {sym }} ; 515 \vee(\mathrm{Zn}-\mathrm{N}) ; 431$ $v(\mathrm{Zn}-\mathrm{O}) ; 189(\Delta v):{ }^{1} \mathrm{HNMR}$ [400 MHz, dimethyl sulfoxide DMSO -d6] $\delta$ (ppm): 2.61 (t, 2H, H2); 2.43 (t, 2H, H3); 9.50 (s, 1H, NH); 8.86 (d, 1H, H6); 7.90 (dd, 1H, H8); 7.17 (d, 1H, H9); 3.85 (s, 3H, H11); 8.67 (d, 1H, Ha); 8.29 (m, 2H, H $\beta) ; 7.95$ (d, 1H, H $\gamma):{ }^{13} \mathrm{C}$ NMR [100 MHz, dimethyl sulfoxide, DMSO-d6] $\delta$ (ppm): 179.4 (C1); 34.1 (C2); 30.2 (C3); 172.7 (C4); 128.2 (C5); 112.5 (C6); 141.5 (C7); 114.9 (C8); 121.9 (C9); 153.2 (C10); 56.3 (C11); $153.7(\mathrm{C} \alpha) ; 119.2(\mathrm{C} \beta) ; 132.5(\mathrm{C} \gamma)$. 


\section{(\{3-[(4-Methoxy-2-Nitrophenyl)}

Carbamoyl] Propanoyl\} Zincio

3-[(2-Methoxy-5-Nitrophenyl)

Carbamoyl] Propanoate Pyridine [Zn $\left(L^{8}\right)_{2}$ (Pyridine)] (AAZ8)

AAZ8 was synthesized utilizing the same procedure as described for AAZ 7, except $\mathrm{NaL}^{8}$ was added in the stoichiometric ratio (7 mmol) instead of $\mathrm{NaL}^{7}$.

Yield: 85\%: M.P. $219-221^{\circ} \mathrm{C}$ : Mol. Wt.: $678.9 \mathrm{~g} / \mathrm{mol}$ : Anal. Calc. (\%) for $\mathrm{C}_{27} \mathrm{H}_{27} \mathrm{~N}_{5} \mathrm{O}_{12} \mathrm{Zn}$ : Calculated (Obtained): C, 47.77 (47.30); H, 4.01 (3.95); N, 10.32 (10.38); O, 28.37 (28.12); Zn, 9.37 (9.645): FT-IR KBr $(4,000-400) v / \mathrm{cm}^{-1}, 3,331 v(\mathrm{NH}) ; 1,677 v\left(\mathrm{CO}_{\text {amide }}\right)$; $1,527 v\left(\mathrm{OCO}_{\text {asym }}\right) ; 1,345 \vee(\mathrm{OCO})_{\text {sym }} ; 508 v(\mathrm{Zn}-\mathrm{N})$; $436 v(\mathrm{Zn}-\mathrm{O}) ; 182(\Delta v):{ }^{1} \mathrm{HNMR}$ [400 MHz, dimethyl sulfoxide DMSO -d6] $\delta(\mathrm{ppm}): 2.59(\mathrm{t}, 2 \mathrm{H}, \mathrm{H} 2) ; 2.40(\mathrm{t}$, 2H, H3); 9.46 (s, 1H, NH); 8.93 (d, 1H, H6); 7.88 (dd, 1H,
H7); 7.14 (d, 1H, H9); 3.89 (s, 3H, H11); 8.65 (d, 1H, H $\alpha$ );

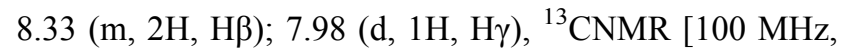
dimethyl sulfoxide, DMSO-d6] $\delta$ (ppm): 179.5 (C1); 34.3 (C2); 30.3 (C3); 172.7 (C4); 127.1 (C5); 109.0 (C6); 139.2 (C7); 116.7 (C8); 119.5 (C9); 149.7 (C10); 56.8 (C11); $152.9(\mathrm{C} \alpha) ; 120.9(\mathrm{C} \beta) ; 129.9(\mathrm{C} \gamma)$.

\section{Anti-Alzheimer Potential}

Acetylcholinesterase and Butyrylcholinesterase Inhibition Activities

To identify the cholinesterase inhibitory potential of both synthesized moieties AAZ7 and AAZ8, a series of dilutions in the order arranged $1,000 \mu \mathrm{g} / \mathrm{mL}$ to $15.62 \mu \mathrm{g} / \mathrm{mL}$ in dimethyl sulfoxide (DMSO) were synthesized and refrigerated to be used for further procedure.

Acetylcholinesterase and butyrylcholinesterase inhibitory potentials were characterized by acquiring acetylcholinesterase and butyrylcholinesterase enzyme from

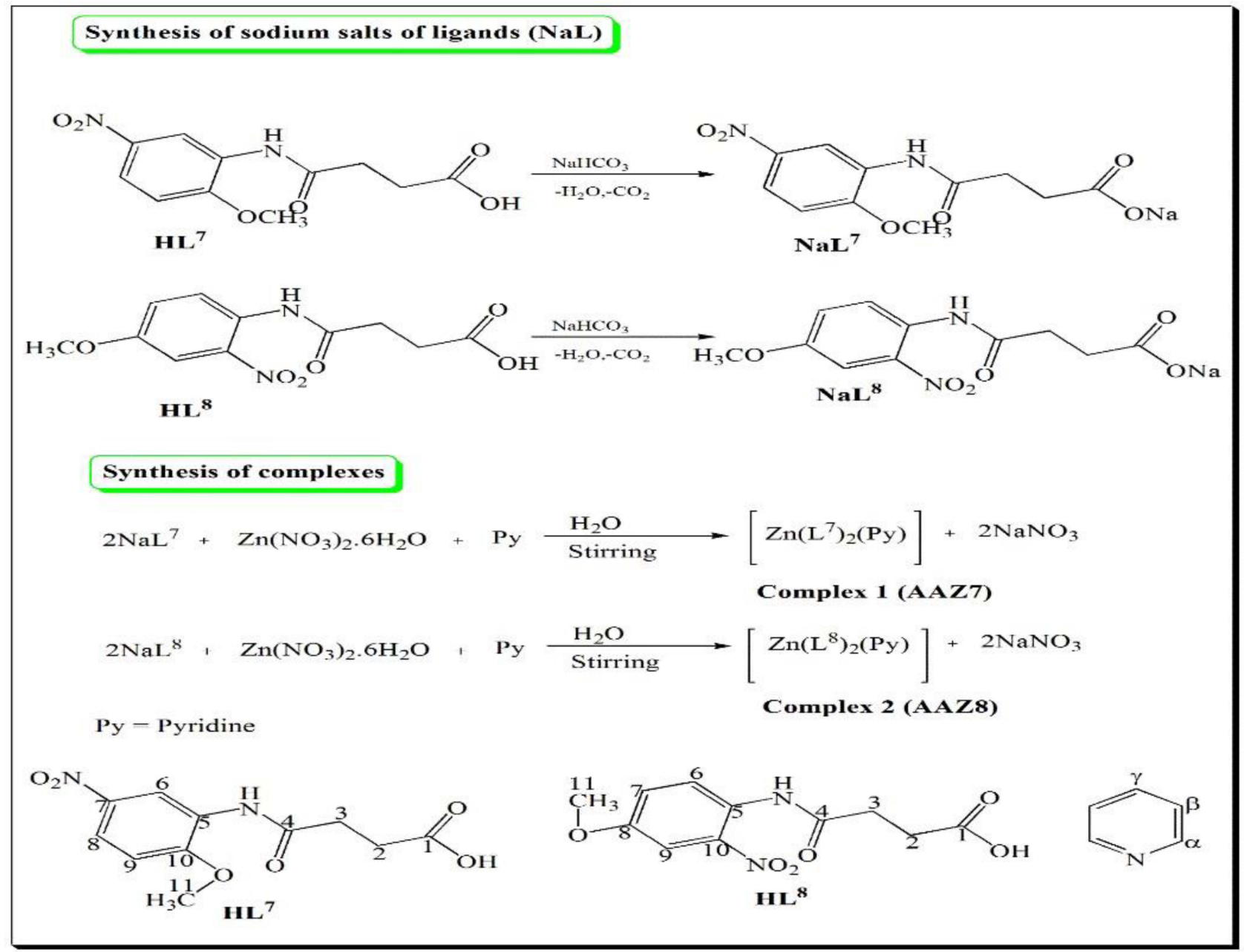

Scheme I Schematic representation of the synthesis of $\mathrm{NaL}^{7}$ and $\mathrm{NaL}^{8}$ and its zinc (II) complexes along with numbering pattern for NMR spectroscopy. 
electric eel and equine serum, respectively, as reported in Ellman's method. ${ }^{43}$ This procedure was based on the formation of anionic radical 5-thio-2-nitrobenzoate. The breakdown of acetylcholine iodide would produce ATchi through acetylcholinesterase or destruction of Butyrylcholine iodide, BTchi through butyrylcholinesterase substrates provided along with enzymes. The complex formation followed the procedure with 5,5-dithio-bisnitrobenzoic acid (DNTB) that gives yellowish color to be analyzed via spectroscopic measurements. The dilutions of newly-synthesized compounds AAZ7 and AAZ8 were blended in freshly prepared $0.1 \mathrm{M}$ phosphate buffer saline (PBS). To obtain 0.03 units per milliliter of AChE and 0.01 units per milliliter of BChE, $518 \mathrm{U} / \mathrm{mg}$ of acetylcholinesterase and $12 \mathrm{U} / \mathrm{mg}$ of butyrylcholinesterase was dissolved in PBS. Furthermore, aliquots of $13.5 \mathrm{~g} / \mathrm{L}$ $(6 \%) \mathrm{KH}_{2} \mathrm{PO}_{4}$, potassium dihydrogen phosphate, along with $17.4 \mathrm{~g} / \mathrm{L}(94 \%)$ of $\mathrm{K}_{2} \mathrm{HPO}_{4}$ dipotassium hydrogen phosphate was synthesized and diversified. The substrates acetylcholine iodide and butyrylcholine iodide were taken in the concentration of $0.5 \mathrm{mM}$, which further combined with $0.2273 \mathrm{mM}$ of DNTB to form a solution in water and was refrigerated for some time at $8^{\circ} \mathrm{C}{ }^{44}$ Galantamine solution was synthesized by dissolving in methanol and taken as the positive control. After synthesizing all the required materials to carry out the procedure, the performance was done by taking each dilution of the synthesized compound, enzyme, and DNTB in the range of $1 \mathrm{~mL}, 50 \mu \mathrm{L}$, and $50 \mu \mathrm{L}$, respectively. These under investigation samples were allowed to incubate at $30^{\circ} \mathrm{C}$ in an incubator for 15 minutes. After the passage of this period, in each incubated dilution, a further $50 \mu \mathrm{L}$ substrate solution was mixed, so enzymes' action can nullify that substrate. These samples were run at $412 \mathrm{~nm}$, and absorbance was measured while taking phosphate buffer saline and all other solvents as blank to not affect the results. $^{45}$

Galantamine absorbance was measured without the addition of any other reagent or sample. We then took two values of each dilution sample: an initial value and the other as the final value after 4 minutes. All readings were taken as triplicate as standard error mean (SEM). The formula's final calculations were reported ${ }^{43}$ by measuring the change in absorbance with change in the dilution. The concentration of dilutions of a synthesized compound that gives the inhibition of $\mathrm{AChE}$ and $\mathrm{BChE}$ by $50 \%$ was calculated. Utilized linear regression method by
Microsoft excel was utilized to manipulate the inhibitory percentage against the diluted concentrations. ${ }^{12,46,47}$

\section{Anti-Oxidant Assays DPPH Scavenging Assay}

DPPH scavenging activity works on free radical scavenging aptitude of 1,1-diphenyl, 2-picrylhydrazyl DPPH, which calculates the antioxidant potential of both synthesized moieties AAZ7 and AAZ8 according to the procedure as explained. ${ }^{46,48}$ A series of five dilutions ranging from $15.62 \mu \mathrm{g} / \mathrm{mL}$ to $1,000 \mu \mathrm{g} / \mathrm{mL}$ of the synthesized compound was synthesized. Each dilution $(0.1 \mathrm{~mL})$ was taken, which was allowed to add with $0.004 \%$ solution of DPPH previously diluted with methanol. ${ }^{49}$

The dilutions were kept incubated for half an hour, and, after that, UV spectrophotometer absorbance was performed at $517 \mathrm{~nm}$. Calculated antioxidant DPPH scavenging ability was calculated by taking the percentage of the ratio of absorbance (control) subtracting absorbance (sample) by absorbance (control) solely. Positive control was ascorbic acid. All the calculated readings were in triplicate. The Graph pad prism statistical approach was utilized to get the inhibitory curve and $\mathrm{IC}_{50}$ values of both synthesized compounds and all dilutions. ${ }^{50}$

\section{ABTS Scavenging Assay}

2, 2-azinobis [3-ethylbenzthiazoline]-6-sulfonic acid (ABTS) was utilized in this assay to calculate the scavenging ability of both synthesized chemical moieties. ${ }^{51}$ This procedure was based on the capability of compounds to knock out the ABTS negatively charged radical that declines the absorbance when measuring at $734 \mathrm{~nm}$ in a UV spectrophotometer. The assay was carried out by a procedure explained previously (reference). Then $245 \times 10^{-3} \mathrm{M}$ solution of ABTS and $7 \times 10^{-3} \mathrm{M}$ solution of $\mathrm{K}_{2} \mathrm{~S}_{2} \mathrm{O}_{4}$ were synthesized and mixed homogeneously. In order to get the dark-colored ABTS cationic radical that would be utilized for assay, the mixture mentioned above was allowed to stand at midnight for 12-16 hours in a fully covered dark area at a typical temperature so that light would not disturb the formation of radicals. For further standardization of this solution, it was allowed to run on a spectrophotometer at $734 \mathrm{~nm}$, and 0.01 $\mathrm{M}$ phosphate buffer solution was added until the absorbance came to 0.70 . A prepared series of dilutions from $15.62 \mu \mathrm{g} / \mathrm{mL}$ to $1,000 \mu \mathrm{g} / \mathrm{mL}$ of synthesized compound was simultaneous. After the attenuation of 0.70 absorbances, standardized solution $(3 \mathrm{~mL})$ was added to each 
dilution series $(300 \mu \mathrm{L})$. All the further procedures to check the scavenging ability of synthesized compounds after mixing of solutions should be carried out in 6 minutes to get the maximum results; otherwise, results may variate due to compatibilities. Results were generated by taking the percentage of the ratio of absorbance (control) subtracting absorbance (sample) by the absorbance (control). Positive control (ascorbic acid) values were taken at the same wavelength at which other dilutions were calculated. Results were performed, and data was manipulated as triplicates. Then $50 \%$ inhibitory potentials, ie, $\mathrm{IC}_{50}$ values, were generated through graph pad prism updated software 5.00 , and values were calculated. ${ }^{52}$

\section{Molecular Docking}

Computational studies were carried out to analyze the binding interaction of synthesized compounds on the targeted $\mathrm{AChE}$ and $\mathrm{BChE}$ enzymes using Autodock Vina 1.1.2 intermitted with PyRx molecular docking software. ${ }^{53}$ The three-dimensional structures of enzymes for acetylcholinesterase as PDB ID 1EVE and butyrylcholinesterase as PDB ID 1P0I were acquired through RCSB protein data bank and saved in PDB format. ${ }^{54}$ These enzymes were modified after removal of water molecules and addition of polar hydrogen. The synthesized compounds AAZ7 and AAZ8 were prepared for docking by converting in PDB format by drawing on Marvin sketch and keeping it as a Mol.file. This file was reopened in another software called Bio viaDiscovery studio visualizer DSV and structures were modified by adding polar hydrogen and saved as PDB. Now both structures and proteins were ready for docking. All the procedures were followed as described in our previous reported research. ${ }^{42}$

\section{Molecular Dynamic Simulations}

Molecular dynamic (MD) simulations are performed to identify the stable conformations and stability patterns of synthesized compounds with protein receptors which was carried out by iMODS that is a quick, adequate, authentic, and approachable way of determining the stability of proteins. ${ }^{55}$ iMODS can be adopted to determine the variance, covariance map, eigenvalues, deformability, and elasticity network data. The best docking model of both ligands was selected and opened in Pymol with targeted protein and saved in pdb format as one molecule. Afterwards parameters were analyzed through iMODS.

\section{Results and Discussions}

\section{Chemistry}

The NaL (7 and 8) and synthesized complexes were characterized by FT-IR spectroscopy, which gives essential data about solid-state complexes. FT-IR data of the bands of our focus were those that were associated with $\mathrm{vOH}$, $v \mathrm{CO}, v \mathrm{NH}, v \mathrm{COO}, v \mathrm{Zn}-\mathrm{N}, v \mathrm{Zn}-\mathrm{O}$ of the $\mathrm{NaL}$, and its complexes. The NaL formation was confirmed by $\mathrm{OH}$ peak's disappearance, which appeared at $3,326 \mathrm{~cm}^{-1}$ in free ligand, suggesting the sodium salt formation. Afterward, this $\mathrm{NaL}$ was utilized as initiative material for complex formation. The binding of the carboxylate moiety in complexes (AAZ7 and AAZ8) was confirmed by the presence of new stretching vibrations at 431 and $436 \mathrm{~cm}^{-1}$, respectively, in the FT-IR spectrum, which can be attributed to $\mathrm{Zn}-\mathrm{O} .{ }^{56}$ From the FT-IR data, binding patterns of carboxylate moiety with central zinc in complexes were measured through the difference of asymmetric $\left(\mathrm{vOCO}_{\text {asym }}\right)$ and symmetric $\left(\mathrm{vOCO}_{\text {sym }}\right)$ stretching vibrations $\left(\Delta v=v \mathrm{COO}_{\text {asym }}-v \mathrm{COO}_{\text {sym }}\right)(5)$. From the FT-IR spectrum, the $\Delta\left(\mathrm{COO}^{-}\right)$values calculated for $\mathrm{NaL}^{7}$ and $\mathrm{NaL}^{8}$ are 256 and $248 \mathrm{~cm}^{-1}$, respectively, while for complexes (AAZ7 and AAZ8), $\Delta v$ is 189 and $182 \mathrm{~cm}^{-1}$, respectively, showing carboxylate moiety bidentate mode with zinc in the solid phase. ${ }^{41}$ Additionally, the pyridine group attachment in both complexes (AAZ7 and AAZ8) was ascertained by the presence of some new stretching vibrations at $515 \mathrm{~cm}^{-1}$ and $508 \mathrm{~cm}^{-1}$, respectively. ${ }^{56}$ Furthermore, the ${ }^{1} \mathrm{HNMR}$ spectra for the $\mathrm{NaL}$ and its zinc (II) complexes (AAZ7 and AAZ8) were calculated in dimethyl sulfoxide by using Tetramethylsilane (standard). The ${ }^{1} \mathrm{H}-\mathrm{NMR}$ is an important tool to give information about complex formation. In both complexes, positions $2(\mathrm{H} 2)$ and $3(\mathrm{H} 3)$ displayed aliphatic protons as a triplet, while there is no noteworthy change in $\mathrm{NH}$ signal that indicates the absence of nitrogen involvement in zinc coordination. Phenyl protons in both the complexes appear in the range of 7.22-8.89 ppm. The appearance of characteristic peaks in the range of 7.12-8.73 ppm confirmed the presence of a pyridine ring. While ${ }^{13} \mathrm{CNMR}$ data of the $\mathrm{NaL}$ and its $\mathrm{Zn}$ (II) complexes (AAZ7 and AAZ8) taken in DMSO utilized Tetramethylsilane as an external standard. Here, an incremental method was adopted to assign each carbon atom chemical shift $(\delta)$ value of $\mathrm{NaL}$ and its $\mathrm{Zn}$ (II) complexes and compare them with the literature values. As compared to $\mathrm{NaL}$ precursors, the carbonyl frequencies (stretching) of 
Table I In vitro AChE Inhibitory Values of New Compounds AAZ7 and AAZ8

\begin{tabular}{|c|c|c|c|}
\hline Concentrations $(\mu \mathrm{g} / \mathrm{mL})$ & $\begin{array}{c}\text { AAZ7 } \\
\text { \% Inhibition } \\
\text { (Mean士SEM) }\end{array}$ & $\begin{array}{c}\text { AAZ8 } \\
\% \text { Inhibition } \\
\text { (Mean士SEM) }\end{array}$ & $\begin{array}{c}\text { Galantamine } \\
\% \text { Inhibition } \\
\text { (Mean士SEM) }\end{array}$ \\
\hline $\mathrm{I}, 000$ & $72.65 \pm 1.02$ & $89.32 \pm 0.65 * * *$ & $96.32 \pm 0.75$ \\
\hline 500 & $71.97 \pm 0.25$ & $87.65 \pm 0.87$ & $94.5 I \pm 0.46$ \\
\hline 250 & $69.34 \pm 0.48 * * *$ & $86.35 \pm 0.45$ & $193.42 \pm 0.84$ \\
\hline 125 & $68.65 \pm 0.63$ & $85.52 \pm 0.14 * * *$ & $92.19 \pm 0.43$ \\
\hline 62.5 & $66.12 \pm 0.84 * * *$ & $83.14 \pm 0.74$ & $90.56 \pm 0.87$ \\
\hline 31.25 & $65.32 \pm 1.31$ & $82.97 \pm 0.98 * * *$ & $89.87 \pm 1.64$ \\
\hline 15.62 & $63.17 \pm 0.58$ & $80.45 \pm 0.67 * * *$ & $87.62 \pm 0.47$ \\
\hline $\mathrm{IC}_{50}(\mu \mathrm{g} / \mathrm{mL})$ & 215 & 14 & $<0.1$ \\
\hline $\mathrm{IC}_{50}(\mu \mathrm{m})$ & 317 & 25 & 0.147 \\
\hline
\end{tabular}

Notes: Values are stated as \% inhibition (mean SEM of $n$ 3) and $I C_{50}$ values. The detected calculations might be significantly different as compared to a positive control (Galantamine) $p<0.001 * * *$.

Abbreviations: SEM, standard error Mean; $\mathrm{IC}_{50}$, inhibitory concentration in $50 \%$ of the population.

complexes were downfield shifted. Due to the electron density decrease at the carbon atom attached to the electropositive zinc atom, it happens through an oxygen atom. These values justify the formation of complexes. However, minor changes were observed in the $-\mathrm{CH}_{2}-\mathrm{CH}_{2}$, phenyl carbons, and C-N signals position after the complexes' formation. The carboxylate carbon atom signals in $\mathrm{NaL}$ displayed at $176.0 \mathrm{ppm}$ and $176.9 \mathrm{ppm}$ after zinc complexation moved downfield to 179.4-179.8 $\mathrm{ppm}$. Additionally, three pyridine signals appeared in 155.4 $120.2 \mathrm{ppm}$ and $153.7-119.2 \mathrm{ppm}$.

\section{Acetylcholinesterase Inhibition Potential}

Alzheimer's disease is a neurodegenerative disorder, characterized by dementia in which the brain's major part, ie, hippocampus, is affected along with the appearance of granulovacuolar degenerative bodies, amyloid $\beta$-plaques and neurofibrillary tangles. ${ }^{57}$ Zinc as a trace element has its importance in management of Alzheimer's disease due to its occurrence in many parts of the brain like the olfactory bulb, cerebral neocortex, amygdala, as well as the hippocampus to serve major roles in catalytic, structural, behavioral, and biological functions and neuromodulators. ${ }^{37}$ In an Acetylcholinesterase inhibition study, compound AAZ8 was found to be exhibiting more potential of $89.32 \pm 0.65,87.65 \pm 0.87,86.35 \pm 0.45,85.52$ $\pm 0.14,83.14 \pm 0.74,82.97 \pm 0.98$, and $80.45 \pm 0.67$ enzyme inhibition as mean \pm SEM at the diluted concentration from $1,000 \mu \mathrm{g} / \mathrm{mL}$ to $15.62 \mu \mathrm{g} / \mathrm{mL}$, respectively. The $\mathrm{IC}_{50}$ of AAZ8 was found to be $14 \mu \mathrm{g} / \mathrm{mL}$, which was calculated through the dose-response curve at the same concentrations. Other compound AAZ7 showed inhibitory potential of $72.65 \pm 1.02,71.97 \pm 0.25,69.34 \pm 0.48,68.65$ $\pm 0.63,66.12 \pm 0.84,65.32 \pm 1.31$, and $63.17 \pm 0.58 \mathrm{AChE}$ inhibition as mean \pm SEM at the diluted concentration ranging from $1,000 \mu \mathrm{g} / \mathrm{mL}$ to $15.62 \mu \mathrm{g} / \mathrm{mL}$, respectively. The $\mathrm{IC}_{50}$ of AAZ7 was calculated as $215 \mu \mathrm{g} / \mathrm{mL}$. During this study, Galantamine was observed to be a positive control having the $\mathrm{IC}_{50}$ of $<0.1 \mu \mathrm{g} / \mathrm{mL}$. All the results were collaborated and expressed in Table 1 and Figure 1.

\section{Butyrylcholinesterase Inhibitory Potential}

In characterizing the $\mathrm{BChE}$ potential of the newly synthesized compounds AAZ7 and AAZ8, the latter was found to have a better perspective as the leading candidate and displayed more satisfactory results when compared with positive control Galantamine. At the dilutions from 1,000 $\mu \mathrm{g} / \mathrm{mL}$ to $15.62 \mu \mathrm{g} / \mathrm{mL}$, the percent inhibition was found to be $85.17 \pm 0.87,84.13 \pm 0.45,83.54 \pm 0.74,81.64 \pm 1.04$, $80.72 \pm 0.58,79.31 \pm 0.67$, and $77.93 \pm 0.78$, respectively, as mean \pm SEM. Moderately, other synthesized compounds AAZ7 also give good results against the butyrylcholinesterase enzyme. Percentage inhibition was calculated to be $81.01 \pm 0.14,79.47 \pm 0.58,78.13 \pm 0.95,76.25 \pm 0.31,75.64$ $\pm 0.42,74.95 \pm 0.13$, and $72.42 \pm 0.27$ as mean \pm SEM at different diluted concentrations in the range of $1,000 \mu \mathrm{g} / \mathrm{mL}$ 


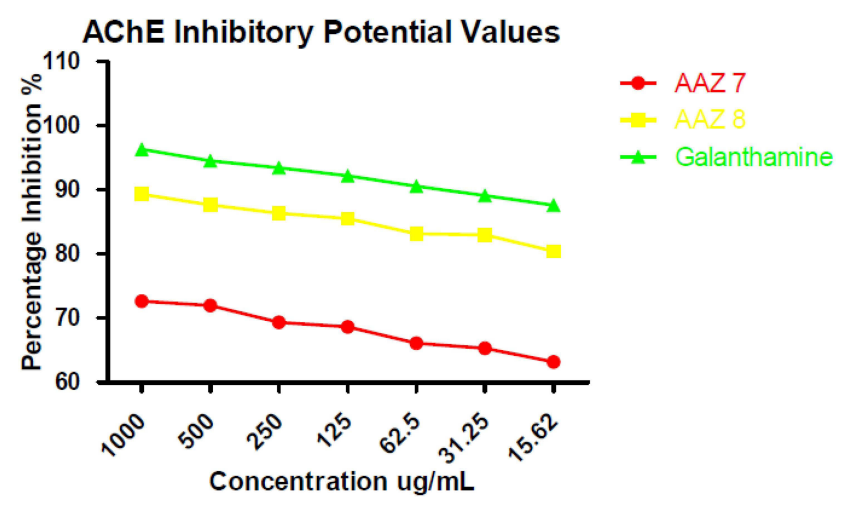

Figure I Graph pad profile of AAZ7 and AAZ8 as AChE inhibitors.

to $15.62 \mu \mathrm{g} / \mathrm{mL}$. The $\mathrm{IC}_{50}$ of $\mathrm{AAZ7}$ and $\mathrm{AAZ8}$ were calculated as $31 \mu \mathrm{g} / \mathrm{mL}$ and $18 \mu \mathrm{g} / \mathrm{mL}$, accordingly compared with the positive control showing an $\mathrm{IC}_{50}$ value of less than $0.1 \mu \mathrm{g} / \mathrm{mL}$. Results were calculated by doseresponse curve, and values were taken as triplicate. Graphs were plotted by the graph pad prism method. Results of both compounds are tabulated in Table 2 and expressed in Figure 2.

\section{DPPH Scavenging Assays}

In DPPH scavenging assays, AAZ8 exhibited the highest scavenging impact in opposition to DPPH radicals with $83.97 \pm 0.12 \%$ radical inhibitory potential at a dilution of $1,000 \mu \mathrm{g} / \mathrm{mL}$. Furthermore at the diluted concentration ranging from $500 \mu \mathrm{g} / \mathrm{mL}$ to $15.62 \mu \mathrm{g} / \mathrm{mL}$, the percentage inhibition was determined to be $81.69 \pm 0.45 \%, 79.54$ $\pm 0.63 \%, 77.85 \pm 0.39 \%, 75.68 \pm 0.97 \%, 73.47 \pm 0.26 \%$, and $69.87 \pm 0.59 \%$, respectively, as mean \pm SEM. An $\mathrm{IC}_{50}$ of AAZ8 was calculated as $35 \mu \mathrm{g} / \mathrm{mL}$, whereas AAZ7 showed $74.16 \pm 0.77 \%$ inhibition of DPPH radicals at $1,000 \mu \mathrm{g} / \mathrm{mL}$ concentration with $\mathrm{IC}_{50}$ of $53 \mu \mathrm{g} / \mathrm{mL}$. These two have been the mightiest fractions among all samples. Other fractions displayed adequate and concentration-dependent inhibitory effects against free DPPH radicals. Positive control was ascorbic acid having an $\mathrm{IC}_{50}$ of less than $0.1 \mu \mathrm{g} / \mathrm{mL}$. Values were calculated as triplicate, and their mean was suggested as the final value for further calculations. Results are expressed in Table 3 and Figure 3.

\section{ABTS Scavenging Assays}

ABTS scavenging potential of synthesized compounds AAZ7 and AAZ8 are summarized in Table 4. Results indicated that AAZ8 has more potential towards ABTS inhibition and displayed $81.35 \pm 0.35 \%, 79.27 \pm 0.64 \%, 78.36 \pm 0.58 \%$, $77.45 \pm 0.87 \%, \quad 73.62 \pm 0.29 \%, \quad 70.28 \pm 0.36 \%, \quad$ and 65.39 $\pm 0.89 \%$ inhibition as mean \pm SEM at the diluted concentration ranging from $1,000 \mu \mathrm{g} / \mathrm{mL}$ to $15.62 \mu \mathrm{g} / \mathrm{mL}$, respectively, as given in Table 4 and having the $\mathrm{IC}_{50}$ of $29 \mu \mathrm{g} / \mathrm{mL}$. In comparison, AAZ7 also showed a moderate percentage inhibitory potential of $80.45 \pm 1.02 \%$ at the highest dilution of $1,000 \mu \mathrm{g} / \mathrm{mL}$. The inhibitory potential of a $50 \%$ population was calculated as $110 \mu \mathrm{g} / \mathrm{mL}$. Values were carried out by the

Table 2 In vitro BChE Inhibitory Values of New Compounds AAZ7 and AAZ8

\begin{tabular}{|c|c|c|c|}
\hline Concentrations $(\mu \mathrm{g} / \mathrm{mL})$ & $\begin{array}{c}\text { AAZ7 } \\
\% \text { Inhibition } \\
\text { (Mean士SEM) }\end{array}$ & $\begin{array}{c}\text { AAZ8 } \\
\% \text { Inhibition } \\
\text { (Mean士SEM) }\end{array}$ & $\begin{array}{l}\text { Galantamine } \\
\% \text { Inhibition } \\
\text { (Mean士SEM) }\end{array}$ \\
\hline 1,000 & $81.01 \pm 0.14$ & $85.17 \pm 0.87^{* * * *}$ & $90.10 \pm 0.73$ \\
\hline 500 & $79.47 \pm 0.58$ & $84.13 \pm 0.45 * * *$ & $88.63 \pm 0.51$ \\
\hline 250 & $78.13 \pm 0.95 * * *$ & $83.54 \pm 0.74$ & $86.25 \pm 0.75$ \\
\hline 125 & $76.25 \pm 0.31$ & $81.64 \pm 1.04 * * *$ & $85.34 \pm 0.67$ \\
\hline 62.5 & $75.64 \pm 0.42^{* * *}$ & $80.72 \pm 0.58$ & $84.97 \pm 0.14$ \\
\hline 31.25 & $74.95 \pm 0.13^{* * *}$ & $79.31 \pm 0.67$ & $83.91 \pm 0.24$ \\
\hline 15.62 & $72.42 \pm 0.27$ & $77.93 \pm 0.78 * * *$ & $82.76 \pm 0.44$ \\
\hline $\mathrm{IC}_{50}(\mu \mathrm{g} / \mathrm{mL})$ & 31 & 18 & $<0.1$ \\
\hline $\mathrm{IC}_{50}(\mu \mathrm{m})$ & 45 & 26.5 & 0.132 \\
\hline
\end{tabular}

Notes: Values are stated as \% inhibition (mean SEM of $n$ 3) and $\mathrm{IC}_{50}$ values. The detected calculations might be significantly different as compared to positive control (Galanthamine), $p<0.001^{* * * *}$.

Abbreviations: SEM, standard error mean; $\mathrm{IC}_{50}$, the concentration required to inhibit $50 \%$ of the population. 
Table 3 In vitro DPPH Free Radical Scavenging Activity of New Compounds AAZ7 andAAZ8

\begin{tabular}{|c|c|c|c|}
\hline Concentrations $(\mu \mathrm{g} / \mathrm{mL})$ & $\begin{array}{c}\text { AAZ7 } \\
\% \text { Inhibition } \\
\text { (Mean士SEM) }\end{array}$ & $\begin{array}{c}\text { AAZ8 } \\
\% \text { Inhibition } \\
\text { (Mean士SEM) }\end{array}$ & $\begin{array}{l}\text { Ascorbic Acid } \\
\% \text { Inhibition } \\
\text { (Mean } \pm \text { SEM) }\end{array}$ \\
\hline 1000 & $74.16 \pm 0.77^{* * *}$ & $83.97 \pm 0.12$ & $95.63 \pm 0.12$ \\
\hline 500 & $71.65 \pm 0.14$ & $81.69 \pm 0.45 * * *$ & $93.65 \pm 0.54$ \\
\hline 250 & $68.25 \pm 0.64$ & $79.54 \pm 0.63 * * *$ & $91.54 \pm 0.37$ \\
\hline 125 & $66.34 \pm 0.17$ & $77.85 \pm 0.39 * * *$ & $87.25 \pm 0.48$ \\
\hline 62.5 & $65.02 \pm 1.0 * * *$ & $75.68 \pm 0.97$ & $84.44 \pm 0.15$ \\
\hline 31.25 & $63.78 \pm 0.51$ & $73.47 \pm 0.26 * * *$ & $82.74 \pm 0.23$ \\
\hline 15.62 & $61.64 \pm 0.78^{* * *}$ & $69.87 \pm 0.59$ & $77.28 \pm 0.79$ \\
\hline $\mathrm{IC}_{50}(\mu \mathrm{g} / \mathrm{mL})$ & 53 & 17 & $<0.1$ \\
\hline $\mathrm{IC}_{50}(\mu \mathrm{m})$ & 78 & 29 & 0.173 \\
\hline
\end{tabular}

Notes: Values are stated as \% inhibition (mean SEM of $n 3$ ) and $I_{50}$ values. The detected calculations might be significantly different as compared to a positive control (Ascorbic acid), $p<0.001 * * *$.

Abbreviations: SEM, standard error mean; $I_{50}$, inhibitory concentration in half of population.

graph pad prism method, and readings were taken as triplicates. Results are demonstrated in Table 4 and Figure 4.

\section{Docking Studies}

For better understanding of synthesized chemical moieties behavior as enzyme inhibitor, docking studies were carried out. Both synthesized compounds AAZ7 and AAZ8 exhibited promising results by showing the binding energies in $\mathrm{AChE}$ as -10.1 and $-9.8 \mathrm{kcal} / \mathrm{Mol}$, respectively, in their best postures. In $\mathrm{BChE}$, they displayed -8.7 and $-8.9 \mathrm{kcal} /$ Mol, respectively. These energies indicated that both of these ligands have excellent potential to act as an enzyme inhibitor. Furthermore, when $3 \mathrm{~d}$ binding of both compounds was analyzed, they gave excellent interaction inside active site of $\mathrm{AChE}$ and $\mathrm{BChE}$ enzymes. Figure 5

\section{BChE Inhibitory Potential values}

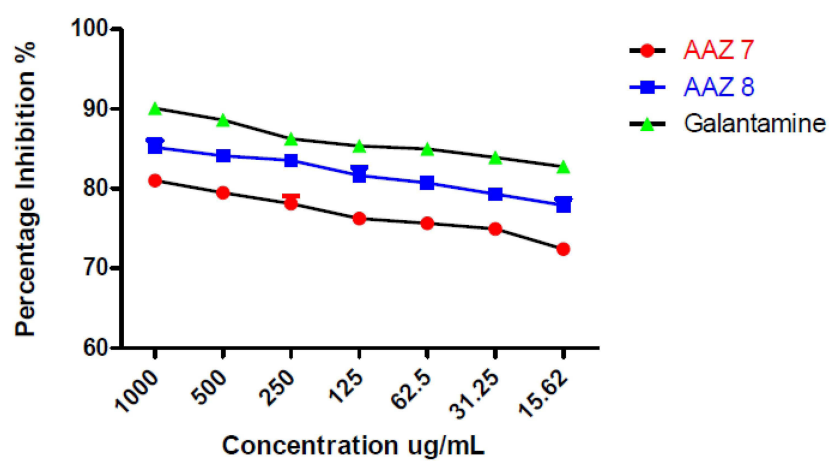

Figure 2 Graph pad profile of AAZ7 and AAZ8 as BChE inhibitors. displays AAZ7 inside the binding pocket of acetylcholinesterase. It has three conventional hydrogen bonds between the carboxylate group and methoxy group on one side and ARG A: 289, PHE A: 288, and TYR A: 121 on the other side with the bond distance of $2.12 \AA$, $2.27 \AA$, and $1.98 \AA$, respectively. Another important type of bonding interaction was observed as pi-pi-T-shaped that appeared between TRP A: 279 and TYR A: 334 with that of heterocyclic pyridine ring. Carbon hydrogen bond also prompt to have the affinity in between ASP A: 72 and benzene ring.

When analyzing the results of AAZ7 inside butyrylcholinesterase enzyme as depicted in Figure 6, outcomes were more realistic and good, due to the presence of multiple bonding patterns. Four conventional hydrogen

\section{DPPH Free Radical Scavenging Activity}

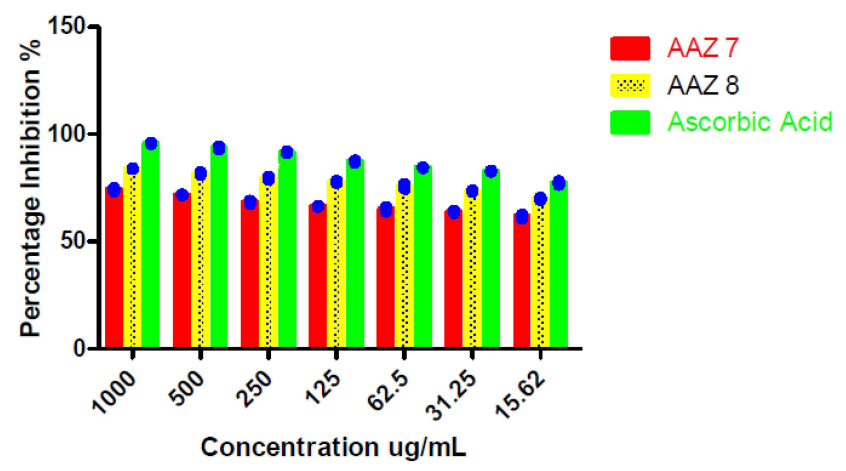

Figure 3 Graph pad profile of AAZ7 and AAZ8 as DPPH free radical scavengers. 
Table 4 In vitro ABTS Free Radical Scavenging Activity of Newly Synthesized AAZ7 and AAZ8

\begin{tabular}{|c|c|c|c|}
\hline Concentrations $(\mu \mathrm{g} / \mathrm{mL})$ & $\begin{array}{c}\text { AAZ7\% } \\
\text { Inhibition } \\
\text { (Mean士SEM) }\end{array}$ & $\begin{array}{c}\text { AAZ8\% } \\
\text { Inhibition } \\
\text { (Mean士SEM) }\end{array}$ & $\begin{array}{l}\text { Ascorbic Acid } \\
\% \text { Inhibition } \\
\text { (Mean } \pm \text { SEM) }\end{array}$ \\
\hline 1,000 & $80.45 \pm 1.02$ & $81.35 \pm 0.35$ & $92.36 \pm 0.65$ \\
\hline 500 & $75.36 \pm 0.69$ & $79.27 \pm 0.64 * * *$ & $88.25 \pm 0.87$ \\
\hline 250 & $71.85 \pm 0.57^{* * *}$ & $78.36 \pm 0.58$ & $85.34 \pm 0.47$ \\
\hline 125 & $68.27 \pm 0.24$ & $77.45 \pm 0.87^{* * *}$ & $84.68 \pm 0.56$ \\
\hline 62.5 & $65.24 \pm 0.38 * * *$ & $73.62 \pm 0.29$ & $81.75 \pm 0.85$ \\
\hline 31.25 & $64.95 \pm 0.74$ & $70.28 \pm 0.36 * * *$ & $79.29 \pm 0.91$ \\
\hline 15.62 & $63.21 \pm 0.16^{* * *}$ & $65.39 \pm 0.89$ & $77.65 \pm 0.32$ \\
\hline $\mathrm{IC}_{50}(\mu \mathrm{g} / \mathrm{mL})$ & 110 & 29 & $<0.1$ \\
\hline $\mathrm{IC}_{50}(\mu \mathrm{m})$ & 190 & 41 & 0.129 \\
\hline
\end{tabular}

Notes: Values are stated as \% inhibition (mean SEM of $\mathrm{n} \mathrm{3)}$ and $\mathrm{IC}_{50}$ values. The detected calculations might significantly different as compared to a positive control (Ascorbic acid), $p<0.001 * * *$.

Abbreviations: SEM, standard error mean; $I_{50}$, inhibitory concentration in half of population.

bonds were appeared with SER A: 72, GLN A: 71, TYR A: 128 , and THR A: 120 with a bond distance of $2.57 \AA$, $2.09 \AA, 2.48 \AA$, and $2.53 \AA$, respectively. Other bonds include $\pi-\pi$-T-shaped and $\pi-\pi$ stacked in between TRY A: 332 with benzene ring and TRP A; 231 and PHE A: 329 with heterocyclic pyridine ring that indicated the important role of the pyridine ring in inhibition of enzyme and performing biological functions. THR A: 284, TRP A: 82, and ASN A: 83 were found to have a carbon hydrogen bonding pattern.

When analyzing the AAZ8 inside the binding pocket of acetylcholinesterase enzyme as shown in Figure 7, multiple interactions give a strong potential of this chemical moiety to get attached with enzyme. Bond lengths of all

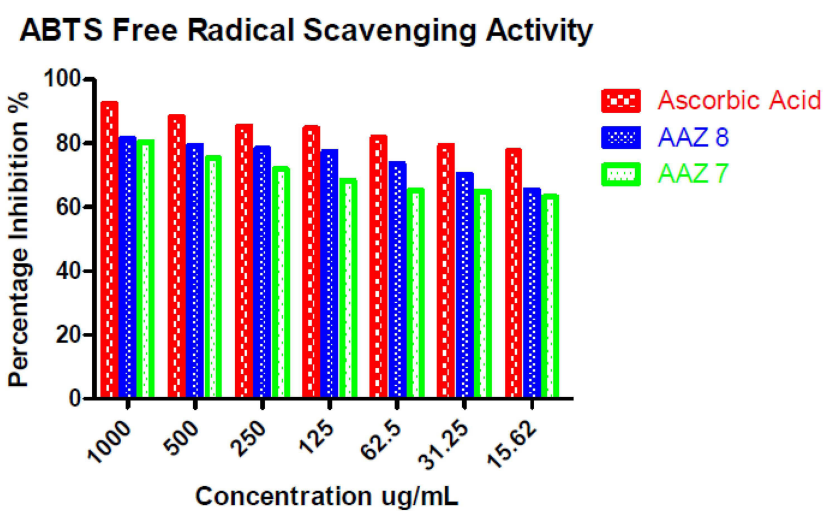

Figure 4 Graph pad profile of AAZ7 and AAZ8 as ABTS free radical scavengers. bonds lie between 2-5 Angstrom which indicated the strength of bonds. Phenyl ring gave pi-pi stacked and pipi-T shaped interaction with PHE A: 330 and PHE A: 331. Strong conventional hydrogen bonds were observed with TYR A: 121, PHE A: 288, and GLY A: 119. The enzyme inhibition was further supported by the Pi-cation interaction that was found between TRP A: 279 and pyridine ring that authenticates the role of the pyridine ring in biological activity. Other amino acid residues include TRP A: 84, GLU A: 199, and HIS A: 440.

When analyzing the binding pattern of AAZ8 with butyrylcholinesterase, the results indicate the presence of three conventional hydrogen bonds, two pi-pi stacked bonds, one carbon hydrogen bond, one amide-pi stacked bond, and one pi-anion bond as given in Figure 8. The insight visualization of bonding pattern showed GLY A: 116, GLY A: 117 and ASN A: 289 involved in conventional hydrogen bond carboxylate group and methoxy side chain. Benzene moiety gave important pi-anion interaction with ASP A: 70 and benzene ring with bond distance of $4.16 \AA$.

\section{Simulations Analysis}

To investigate the thermodynamic parameters utilizing molecular dynamic simulation is one of the powerful tool to determine the ligand protein stability and flexibility. The NMA normal mode analysis of synthesized complexes are explained in Figures 9A and 10A. Through the molecular dynamics simulations study, it was calculated that AAZ7 as 


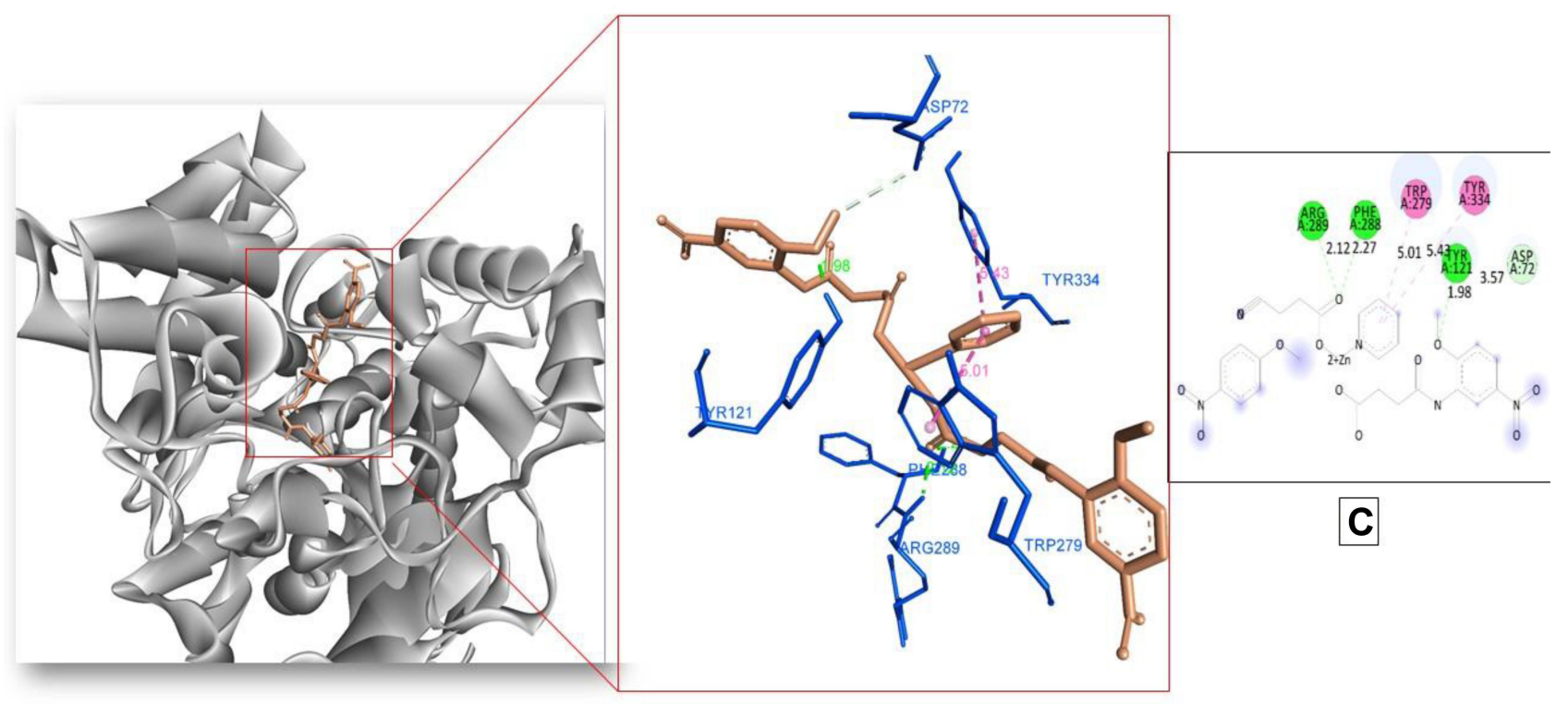

A

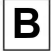

Figure 5 Docking model of AAZ7 interacting with acetylcholinesterase AChE enzyme. (A) Structure of synthesized compound AAZ7 (brown) at a specific site inside protein cartoon model (white). (B) Three dimensional display of AAZ7 (brown) with amino acid residue (blue) at the binding site with bond distance shown. (C) Twodimensional visualization of AAZ7 at the enzyme binding site with bonding patterns and bond distance shown.

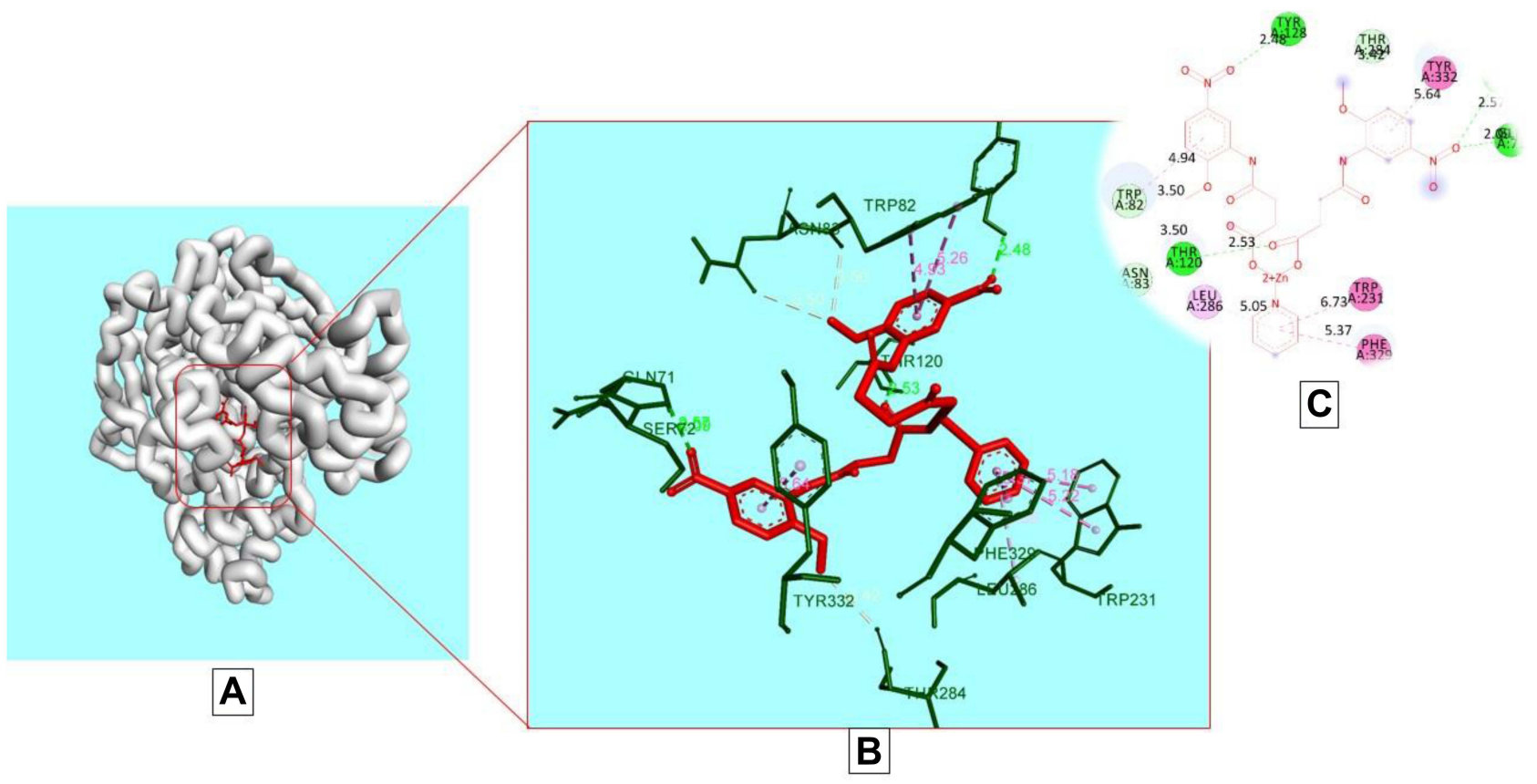

Figure 6 Docking model of AAZ7 interacting with butyrylcholinesterase BChE enzyme. (A) Structure of synthesized compound AAZ7 (red) at a specific site inside protein cartoon model (white). (B) Three- dimensional display of AAZ7 (red) with amino acid residue (green) at the binding site with bond distance shown. (C) Two-dimensional visualization of AAZ7 at the enzyme binding site with bonding patterns and bond distance shown. 


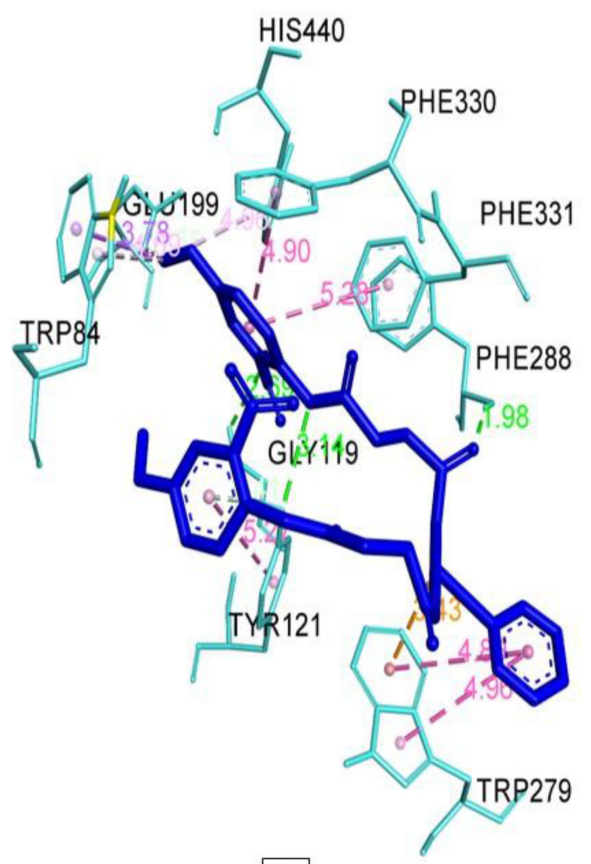

A

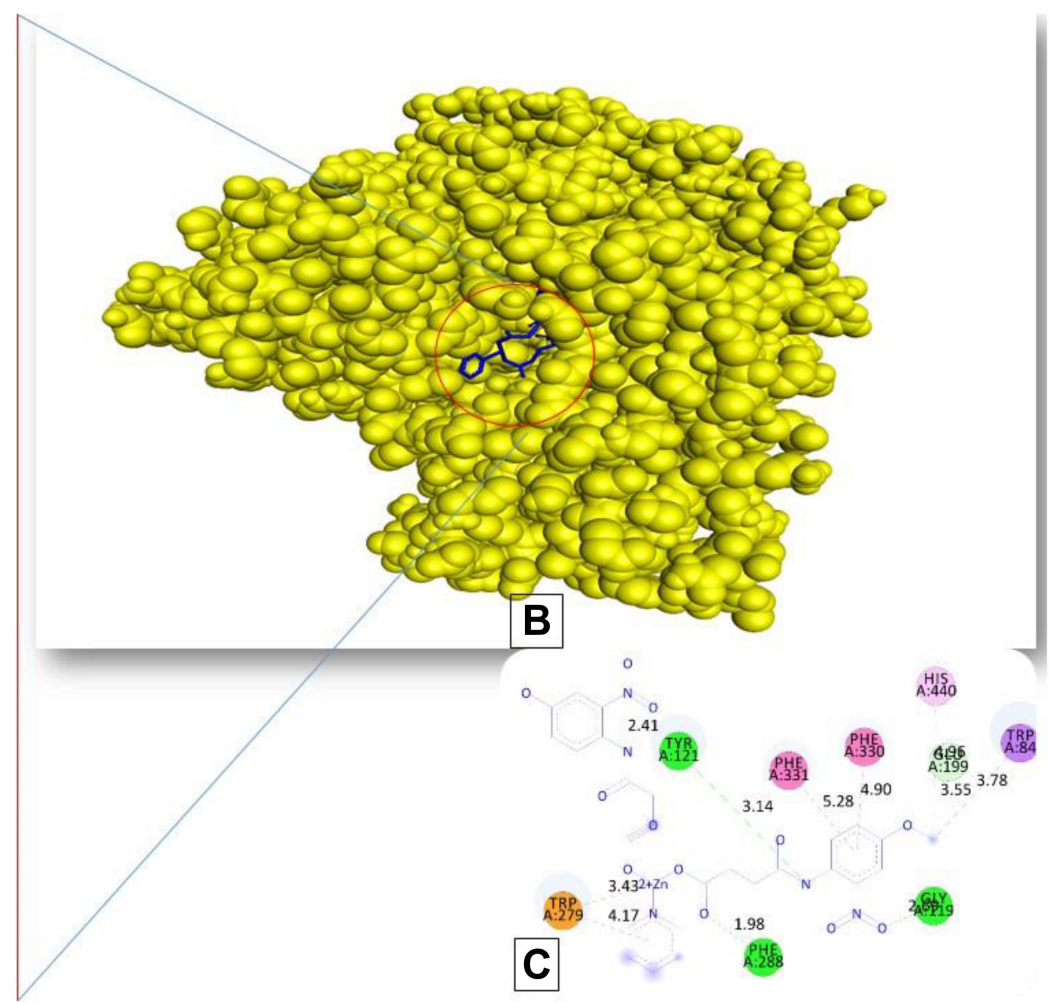

Figure 7 Docking model of AAZ8 interacting with acetylcholinesterase AChE enzyme. (A) Structure of synthesized compound AAZ8 (blue) at a specific site inside protein cartoon model (yellow).(B) Three- dimensional display of AAZ7 (blue) with amino acid residue (light blue) at the binding site with bond distance shown. (C) Twodimensional visualization of AAZ7 at the enzyme binding site with bonding patterns and bond distance shown.

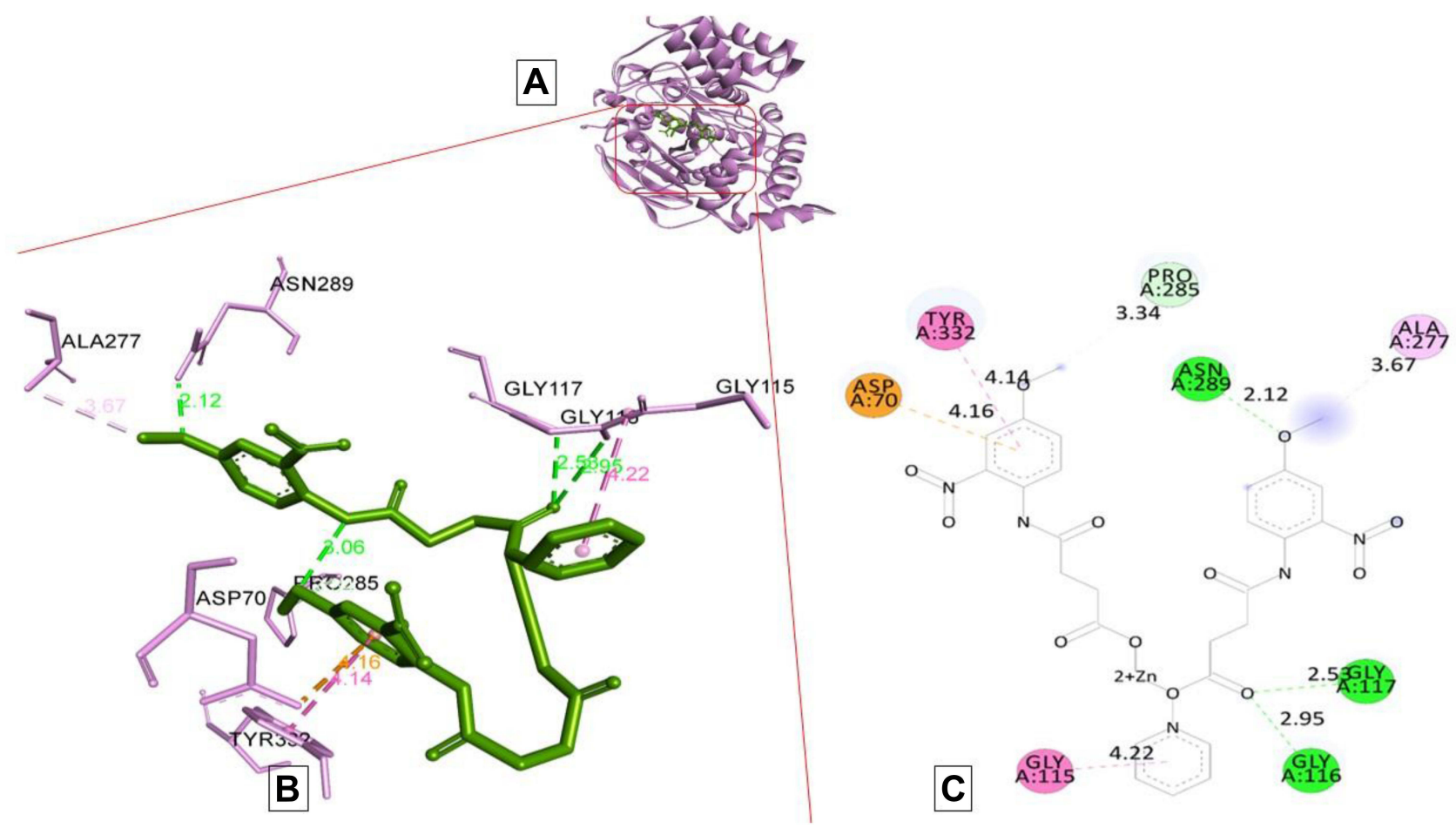

Figure 8 Docking model of AAZ8 interacting with butyrylcholinesterase BChE enzyme. (A) Structure of synthesized compound AAZ8 (green) at a specific site inside protein cartoon model (purple). (B) Three- dimensional display of AAZ8 (green) with amino acid residue (purple) at the binding site with bond distance shown. (C) Twodimensional visualization of AAZ8 at the enzyme binding site with bonding patterns and bond distance shown. 


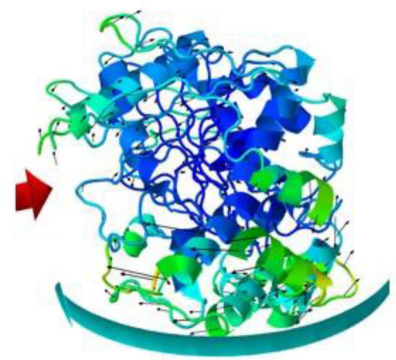

A

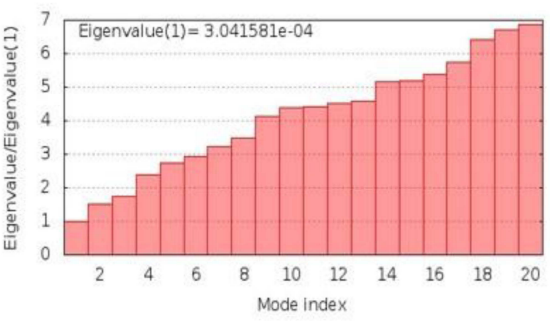

B

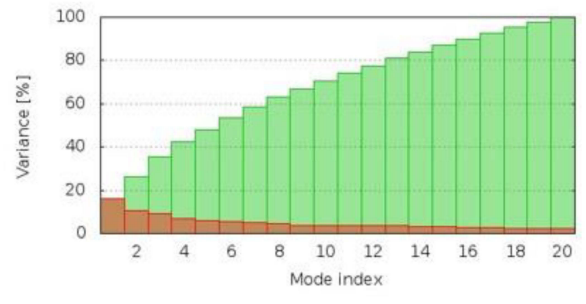

C

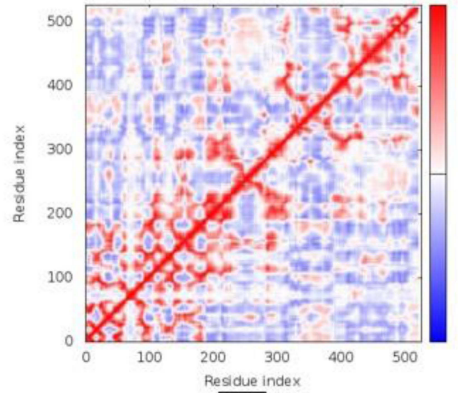

D

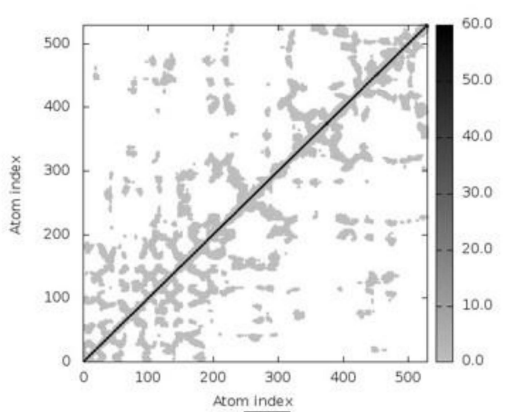

E

Figure 9 Results of molecular dynamics simulations of AAZ7 docked complex with BChE. (A) NMA mobility, (B) eigenvalues, (C) variance (red color represents individual variance in comparison with green color representing cumulative variance), (D) covariance map correlated in red color, uncorrelated in white color and blue color giving correlated, (E) elastic region as more grey area represents more hard regions.

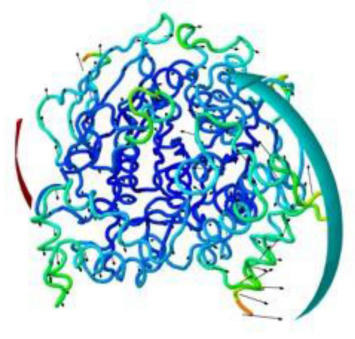

A

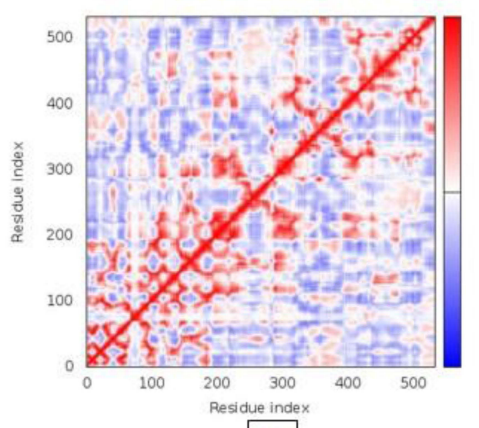

D

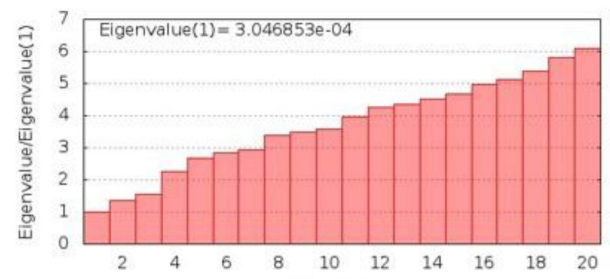

B

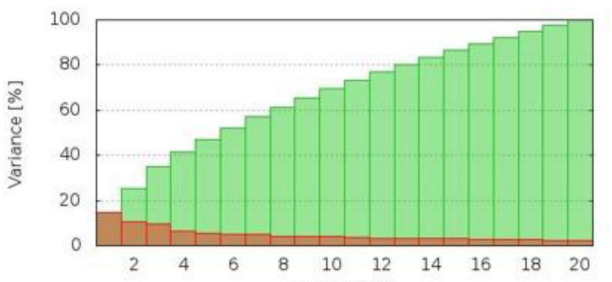

C

Figure 10 Results of molecular dynamics simulations of AAZ8 docked complex with AChE. (A) NMA mobility, (B) eigenvalues, (C) variance (red color represents individual variance in comparison with green color representing cumulative variance), (D) covariance map correlated in red color, uncorrelated in white color and blue color giving correlated, (E) elastic region as more grey area represents more hard regions. 
a ligand protein complex has the eigenvalue of 3.041581e04 and AAZ8 has the eigenvalue of 3.046853e-04 that represents high stability of both complexes inside protein, as given in Figures 9B and 10B. The variance maps indicate the high value of cumulative variance in comparison with individual variance digits as given in Figures 9C and 10C. Elastic map and covariance also gave promising results, as given in Figure 9Ds and E and 10D and E. Overall the two synthesized ligands AAZ7 and AAZ8 have the potential to inhibit cholinesterase enzymes.

\section{Conclusions}

We summarized our results as we have successfully synthesized two novel carboxylates containing amide zinc (II) complexes (AAZ7 and AAZ8) linked with the heterocyclic pyridine ring. The synthesized compounds were characterized through FT-IR, 1H_NMR, 13C_NMR, and elemental analysis to confirm the formation of complexes. The designed compounds showed promising in vitro anticholinesterase and antioxidant activities. Compound AAZ8 proved to have excellent potential by showing $\mathrm{IC}_{50}$ values of $215 \mu \mathrm{g} / \mathrm{mL}$ and $18 \mu \mathrm{g} / \mathrm{mL}$ against $\mathrm{AChE}$ and $\mathrm{BChE}$, respectively. Both the compounds displayed antioxidant potential indicating the free radical scavenging ability of synthesized compounds. Molecular docking studies confirmed the ligand-receptor binding interactions with excellent negative binding energies. Molecular kinetic simulations studies were performed that supported the stability and flexibility of synthesized chemical moieties with targeted proteins. The current study indicates that AAZ8 is a promising candidate and can become a valuable approach for managing AD.

\section{Acknowledgments}

The authors are highly thankful to the Department of Chemistry, Quaid-i-Azam University, Islamabad, for research support. The authors acknowledge the contribution of the University of Malakand for performing biological activities. We also thank the Higher Education Commission (HEC) of Pakistan for providing IRSIP Scholarship.

\section{Author Contributions}

All authors made a significant contribution to the work reported, whether that is in the conception, study design, execution, acquisition of data, analysis, and interpretation, or in all these areas; took part in drafting, revising, or critically reviewing the article; gave final approval of the version to be published; have agreed on the journal to which the article has been submitted; and agreed to be accountable for all aspects of the work.

\section{Funding}

There is no funding source for this project.

\section{Disclosure}

The authors reported no conflicts of interest for this work.

\section{References}

1. Alzheimer's Association. 2017 Alzheimer's disease facts and figures. Alzheimers Dement. 2017;13(4):325-373.

2. Shah SMM, Sadiq A, Shah SMH, et al. Antioxidant, total phenolic contents and antinociceptive potential of Teucrium stocksianum methanolic extract in different animal models. $B M C$ Complement Altern Med. 2014;14(1):1-7. doi:10.1186/14726882-14-181

3. Tanoli ST, Ramzan M, Hassan A, et al. Design, synthesis and bioevaluation of tricyclic fused ring system as dual binding site acetylcholinesterase inhibitors. Bioorg Chem. 2019;83:336-347. doi:10.1016/j.bioorg.2018.10.035

4. Ghai R, Nagarajan K, Arora M, Grover P, Ali N, Kapoor G. Current strategies and novel drug approaches for Alzheimer disease. CNS Neurol Disord Drug Targets. 2020.

5. Sarfraz M, Sultana N, Rashid U, et al. Synthesis, biological evaluation and docking studies of 2, 3-dihydroquinazolin-4 (1H)-one derivatives as inhibitors of cholinesterases. Bioorg Chem. 2017;70:237-244. doi:10.1016/j.bioorg.2017.01.004

6. Ahmad S, Iftikhar F, Ullah F, et al. Rational design and synthesis of dihydropyrimidine based dual binding site acetylcholinesterase inhibitors. Bioorg Chem. 2016;69:91-101. doi:10.1016/j. bioorg.2016.10.002

7. Tanaka T, Kazui H, Morihara T, et al. Post-marketing survey of donepezil hydrochloride in Japanese patients with Alzheimer's disease with behavioral and psychological symptoms of dementia (BPSD). Psychogeriatrics. 2008;8(3):114-123. doi:10.1111/j.14798301.2008.00250.x

8. Carrol DH, Chassagne F, Dettweiler M, Quave CL. Antibacterial activity of plant species used for oral health against Porphyromonas gingivalis. PLoS One. 2020;15(10):e239316. doi:10.1371/journal. pone. 0239316

9. Aguayo S, Schuh CMAP, Vicente B, et al. Association between Alzheimer's disease and oral and gut microbiota: are pore forming proteins the missing link? J Alzheimers Dis. 2018;65(1):29-46. doi:10.3233/JAD-180319

10. Sadiq A, Mahmood F, Ullah F, et al. Synthesis, anticholinesterase and antioxidant potentials of ketoesters derivatives of succinimides: a possible role in the management of Alzheimer's. Chem Cent J. 2015;9(1):1-9. doi:10.1186/s13065-015-0107-2

11. Markowitz JS, Gutterman EM, Sadik K, et al. Health-related quality of life for caregivers of patients with Alzheimer disease. Alzheimer Dis Assoc Disord. 2003;17(4):209-214. doi:10.1097/00002093200310000-00003

12. Amin MJ, Miana GA, Rashid U, et al. SAR based in-vitro anticholinesterase and molecular docking studies of nitrogenous progesterone derivatives. Steroids. 2020;158:108599. doi:10.1016/j. steroids.2020.108599

13. West MJ, Coleman PD, Flood DG, et al. Differences in the pattern of hippocampal neuronal loss in normal ageing and Alzheimer's disease. Lancet. 1994;344(8925):769-772. doi:10.1016/S0140-6736(94) 92338-8 
14. Jan MS, Ahmad S, Hussain F, et al. Design, synthesis, in-vitro, in-vivo and in-silico studies of pyrrolidine-2, 5-dione derivatives as multitarget anti-inflammatory agents. Eur $J$ Med Chem. 2020;186:111863. doi:10.1016/j.ejmech.2019.111863

15. Uddin MN, Afrin R, Uddin MJ, et al. Vanda roxburghii chloroform extract as a potential source of polyphenols with antioxidant and cholinesterase inhibitory activities: identification of a strong phenolic antioxidant. BMC Complement Altern Med. 2015;15(1):1-9. doi:10.1186/s12906-015-0728-y

16. Stamps JJ, Bartoshuk LM, Heilman KM. A brief olfactory test for Alzheimer's disease. J Neurol Sci. 2013;333(1-2):19-24. doi:10.1016/j.jns.2013.06.033

17. Kawas C, Corrada MM, Brookmeyer R, et al. Visual memory predicts Alzheimer's disease more than a decade before diagnosis. Neurology. 2003;60(7):1089-1093. doi:10.1212/01.WNL.00000 55813.36504.BF

18. Ahmad S, Mahnashi MH, Alyami BA, et al. Synthesis of michael adducts as key building blocks for potential analgesic drugs: in vitro, in vivo and in silico explorations. Drug Design Devel Ther. 2021;15:1299. doi:10.2147/DDDT.S292826

19. Lim KY, Ryan EA, Wong PK, et al. Studies on the pathology, especially brain hemorrhage and angioendotheliomas, induced by two new mos-containing viruses. J Neurovirol. 2000;6(2):106-120. doi:10.3109/13550280009013154

20. Mahnashi MH, Alyami BA, Alqahtani YS, et al. Phytochemical profiling of bioactive compounds, anti-inflammatory and analgesic potentials of Habenaria digitata Lindl.: molecular docking based synergistic effect of the identified compounds. J Ethnopharmacol. 2021;273:113976. doi:10.1016/j.jep.2021.113976

21. Zafar R, Ullah H, Zahoor M, et al. Isolation of bioactive compounds from Bergenia ciliata (haw.) Sternb rhizome and their antioxidant and anticholinesterase activities. BMC Complement Altern Med. 2019;19 (1):1-13. doi:10.1186/s12906-019-2679-1

22. Siddiqui TG, Whitfield T, Praharaju SJ, et al. Magnetic resonance imaging in stable mild cognitive impairment, prodromal alzheimer's disease, and prodromal dementia with lewy bodies. Dement Geriatr Cogn Disord. 2020;1-6.

23. Ahmad G, Rasool N, Rizwan K, et al. Synthesis, in-vitro cholinesterase inhibition, in-vivo anticonvulsant activity and in-silico exploration of N-(4-methylpyridin-2-yl)thiophene-2-carboxamide analogs. Bioorg Chem. 2019;92:103216. doi:10.1016/j. bioorg.2019.103216

24. Sultana N, Sarfraz M, Tanoli ST, et al. Synthesis, crystal structure determination, biological screening and docking studies of N1-substituted derivatives of 2, 3-dihydroquinazolin-4 $(1 \mathrm{H})$-one as inhibitors of cholinesterases. Bioorg Chem. 2017;72:256-267. doi:10.1016/j.bioorg.2017.04.009

25. Tariot PN, Cummings JL, Katz IR, et al. A randomized, double-blind, placebo-controlled study of the efficacy and safety of donepezil in patients with Alzheimer's disease in the nursing home setting. $\mathrm{J} \mathrm{Am}$ Geriatr Soc. 2001;49(12):1590-1599. doi:10.1111/j.15325415.2001.49266.x

26. Shah S, Ahmad Z, Yaseen M, et al. Phytochemicals, in vitro antioxidant, total phenolic contents and phytotoxic activity of Cornus macrophylla Wall bark collected from the North-West of Pakistan. Pak J Pharm Sci. 2015;28(1):23-28.

27. Khan J, Ali G, Rashid U, et al. Mechanistic evaluation of a novel cyclohexanone derivative's functionality against nociception and inflammation: an in-vitro, in-vivo and in-silico approach. Eur J Pharmacol. 2021;902:174091. doi:10.1016/j.ejphar.2021.174091

28. Manzoor S, Prajapati SK, Majumdar S, et al. Discovery of new phenyl sulfonyl-pyrimidine carboxylate derivatives as the potential multi-target drugs with effective anti-Alzheimer's action: design, synthesis, crystal structure and in-vitro biological evaluation. Eur J Med Chem. 2021;215:113224. doi:10.1016/j.ejmech.2021.113224
29. Mak S, Li W, Fu H, et al. Promising tacrine/huperzine A-based dimeric AChE inhibitors for neurodegenerative disorders: from relieving symptoms to modifying diseases through multi-target. $J$ Neurochem. 2021. doi:10.1111/jnc.15379

30. Tong X, Li X, Ayaz M, et al. Neuroprotective studies on Polygonum hydropiper L. essential oils using transgenic animal models. Front Pharmacol. 2020;11.

31. Zeb A, Sadiq A, Ullah F, Ahmad S, Ayaz M. Investigations of anticholinestrase and antioxidant potentials of methanolic extract, subsequent fractions, crude saponins and flavonoids isolated from Isodon rugosus. Biol Res. 2014;47(1):1-10. doi:10.1186/0717-6287-47-1

32. Alonso D, Dorronsoro I, Rubio L, et al. Donepezil-tacrine hybrid related derivatives as new dual binding site inhibitors of AChE. Bioorg Med Chem. 2005;13(24):6588-6597. doi:10.1016/j. bmc.2005.09.029

33. Ahmad A, Ullah F, Sadiq A, et al. Pharmacological evaluation of aldehydic-pyrrolidinedione against HCT-116, MDA-MB231, NIH/3T3, MCF-7 cancer cell lines, antioxidant and enzyme inhibition studies. Devel Ther. 2019;13:4185. doi:10.2147/DDDT. S226080

34. Saleem K, Wani WA, Haque A, et al. Synthesis, DNA binding, hemolysis assays and anticancer studies of copper (II), nickel (II) and iron (III) complexes of a pyrazoline-based ligand. Future Med Chem. 2013;5(2):135-146. doi:10.4155/fmc.12.201

35. Adewumi OA, Singh V, Singh G. Chemical composition, traditional uses and biological activities of artemisia species. Int J Pharmacogn Phytochem. 2020;9(5):1124-1140.

36. Pickles C. Thermodynamic analysis of the separation of zinc and lead from electric arc furnace dust by selective reduction with metallic iron. Sep Purif Technol. 2008;59(2):115-128. doi:10.1016/j. seppur.2007.05.032

37. Blakemore LJ, Trombley PQ. Zinc as a neuromodulator in the central nervous system with a focus on the olfactory bulb. Front Cell Neurosci. 2017;11:297.

38. Mamane V. Cascade reactions involving aromatic N-heterocycles: $\mathrm{CN}$ bond formation as key-step towards the synthesis of N-fused polycyclic heterocycles. Curr Org Chem. 2017;21(15):1342-1392. doi:10.2174/1385272820666160606155222

39. Akhtar S, Ahmad H, Akhtar H, Zafar R, Waseem W, Sherwani MK. Protein kinase inhibitory potential and anti-fungal activities of metal complexes of anti-viral drug ribavirin. RADS J Pharm Pharm Sci. 2019;7(1):9-15.

40. Orellana G, Alvarez Ibarra C, Santoro J. Hydrogen-1 and carbon-13 NMR coordination-induced shifts in a series of tris (. alpha.-diimine) ruthenium (II) complexes containing pyridine, pyrazine, and thiazole moieties. Inorg Chem. 1988;27(6):1025-1030. doi:10.1021/ ic00279a018

41. Zubair M, Sirajuddin M, Haider A, et al. Synthesis, physicochemical characterizations and in vitro biological evaluations of amide based Zn (II) carboxylates. Inorganica Chim Acta. 2018;482:567-578. doi:10.1016/j.ica.2018.07.005

42. Zafar R, Zubair M, Ali S, et al. Zinc metal carboxylates as potential anti-Alzheimer's candidate: in vitro anticholinesterase, antioxidant and molecular docking studies. J Biomol Struct Dyn. 2020;1-11.

43. Ayaz M, Junaid M, Ullah F, et al. Anti-Alzheimer's studies on $\beta$ sitosterol isolated from Polygonum hydropiper L. Front Pharmacol. 2017;8:697. doi:10.3389/fphar.2017.00697

44. Alqahtani YS. Bioactive Stigmastadienone from Isodon rugosus as potential anticholinesterase, $\alpha$-glucosidase and COX/LOX inhibitor: in-vitro and molecular docking studies. Steroids. 2021;172:108857. doi:10.1016/j.steroids.2021.108857

45. Yousaf M, Khan M, Ali M, et al. 2-Mercaptobenzimidazole derivatives as novel butyrylcholinesterase inhibitors: biology-oriented drug synthesis (BIODS), in-vitro and in-silico evaluation. J Chem Soc Pak. 2020;42(2):263-273. 
46. Ahmad A, Ullah F, Sadiq A, et al. Comparative cholinesterase, $\alpha-$ glucosidase inhibitory, antioxidant, molecular docking, and kinetic studies on potent succinimide derivatives. Drug Des Devel Ther. 2020;14:2165. doi:10.2147/DDDT.S237420

47. Zahoor M, Shafiq S, Ullah $\mathrm{H}$, et al. Isolation of quercetin and mandelic acid from Aesculus indica fruit and their biological activities. BMC Biochem. 2018;19(1):1-14. doi:10.1186/s12858018-0095-7

48. Jabeen M, Ahmad S, Shahid K, et al. Ursolic acid hydrazide based organometallic complexes: synthesis, characterization, antibacterial, antioxidant, and docking studies. Front Chem. 2018;6:55. doi:10.3389/fchem.2018.00055

49. Sadiq A, Rashid U, Ahmad S, et al. Treating hyperglycemia from eryngium caeruleum M. bieb: in-vitro $\alpha$-glucosidase, antioxidant, invivo antidiabetic and molecular docking-based approaches. Front Chem. 2020;8:1064. doi:10.3389/fchem.2020.558641

50. Bibi A, Shah T, Sadiq A, et al. L-isoleucine-catalyzed michael synthesis of $\mathrm{N}$-alkylsuccinimide derivatives and their antioxidant activity assessment. Russ J Org Chem. 2019;55(11):1749-1754. doi:10.1134/S1070428019110174

51. Ayaz M, Ahmad I, Sadiq A, et al. Persicaria hydropiper (L.) Delarbre: a review on traditional uses, bioactive chemical constituents and pharmacological and toxicological activities. J Ethnopharmacol. 2020;251:112516. doi:10.1016/j.jep.2019.112516
52. Sadiq A, Zeb A, Ullah F, et al. Chemical characterization, analgesic, antioxidant, and anticholinesterase potentials of essential oils from Isodon rugosus Wall. ex. Benth. Front Pharmacol. 2018;9:623. doi:10.3389/fphar.2018.00623

53. Suwanhom P, Nualnoi T, Khongkow P, Lee VS, Lomlim L. Synthesis and evaluation of chromone-2-carboxamido-alkylamines as potent acetylcholinesterase inhibitors. Med Chem Res. 2020;29 (3):564-574. doi:10.1007/s00044-020-02508-5

54. Scotti L, Mendonca F, Ishiki H, et al. Docking studies for multi-target drugs. Curr Drug Targets. 2017;18(5):592-604. doi:10.2174/ 1389450116666150825111818

55. Shaheen Bibi IU, Ullah I, Zhu B, et al. In silico analysis of epitope-based vaccine candidate against tuberculosis using reverse vaccinology. Sci Rep. 2021;11.

56. Zubair M, Sirajuddin M, Haider A, et al. Organotin (IV) complexes as catalyst for biodiesel formation: synthesis, structural elucidation and computational studies. Appl Organomet Chem. 2020;34(1): e5305. doi:10.1002/aoc.5305

57. Hokkanen SRK. Old-Age Hippocampal Sclerosis in the Aged Population. University of Cambridge; 2018.

\section{Publish your work in this journal}

Drug Design, Development and Therapy is an international, peerreviewed open-access journal that spans the spectrum of drug design and development through to clinical applications. Clinical outcomes, patient safety, and programs for the development and effective, safe, and sustained use of medicines are a feature of the journal, which has also been accepted for indexing on PubMed Central. The manuscript management system is completely online and includes a very quick and fair peer-review system, which is all easy to use. Visit http://www. dovepress.com/testimonials.php to read real quotes from published authors. 